\title{
EARNINGS MANAGEMENT FOR BONUS COMPENSATION
}

\author{
Isyrohil Muyassaroh ${ }^{1}$, Imam Subekti ${ }^{2}$, Zaki Baridwan ${ }^{3}$ \\ 1isymoe.im@gmail.com \\ ${ }^{1}$ IAIN Kediri \\ Jl. Sunan Ampel No.7, Ngronggo, Kec. Kota Kediri, Kota Kediri, Jawa Timur \\ ${ }^{2,3}$ Universitas Brawijaya \\ Jl. Veteran, Ketawanggede, Kec. Lowokwaru, Kota Malang, Jawa Timur
}

received: 21/6/19; revised: 17/2/21; approved: 28/6/21

\begin{abstract}
The objectives of this quantitative study are to investigate the practice of earnings management which is proxied by Loan Loss Provision and Loan Loss Allowance and to assess the effect of bonuses on earnings management practices. Using purposive sampling, 102 banks were selected as the sample. The assessment includes one-sample t test and linear regression test. This study finds that banks commit earnings management practices by reducing LLA values and that bonuses negatively influence the practice of earnings management as proxied by LLP.
\end{abstract}

Keywords: earnings management; loss loans provision; loan loss allowance; bonuses; positive accounting theory

\section{INTRODUCTION}

The number of earnings management research topics in the accounting literature that have been reviewed from each period has attracted the attention of investors, financial analysts, and even academics today. The more researches with various hypotheses related to earnings management in financial and non-financial institutions, the more knowledge will be in developing accounting theory. Earnings management practices have become a fact in the financial statements of companies with various motivations and interests, such as research conducted by Healy and Wahlen, 1998; Achmad, et al., 2007; Subekti, 2010; Abaoub et al., 2013; Habbash and Alghamdi, 2015, and Chhabra, 2016. The phenomenon of earnings management practices, one of which occurs in Indonesia, is the case of Bank Bukopin. Bank Bukopin revised its 2016 net profit in its 2017 annual report to IDR 183.56 billion from IDR 1.08 trillion previously, the largest decrease in fees and commissions, namely income from credit cards (Sugianto, 2018).

The practice of earnings management is one of the results of a conflict of incompatibility between shareholders (principal) and company management (agents) or between majority shareholders and minority shareholders. There are two approaches in conducting earnings management, either by using real earnings management or earning management on an accrual basis. Accrual earnings management is measured by short-term and longterm discretionary accruals, while real earnings management is measured by abnormal operating cash flows, abnormal production costs, and abnormal discretionary costs (Ningsih, 2015). According to Yuanhui et al. (2018), banks cannot identify real earnings management, as is the case with Dechow et al. (1995) stated that banks with higher concentration power can manipulate income through loan terms, fees, margins, and revenues.

Positive accounting theory explains the reasons for the use of accounting policies that are considered to be problems for companies and parties with an interest in financial statements. Positive accounting theory can also predict the accounting policies that companies will use under certain conditions. Bonus design has a positive relationship or influence on earnings management from the perspective of positive accounting theory. Positive accounting theory proposes three hypotheses of earnings management motivation: (1) the bonus plan hypothesis, (2) the debt covenant hypothesis, and (3) the political cost hypothesis (Watts and Zimmerman, 1986). According to Pratiwi (2011), when management's performance in the current year reaches the target, it will be rewarded through a higher bonus, but when management performance exceeds the target or is less than the target, they want to reduce profits for the current year, or allocate the following year. 
Bonus compensation is thought to affect earnings management practices, if bonus compensation is provided by the company to managers in running the company, which is reflected in earnings. According to Gayatrie (2014) tantiem is a popular compensation policy because it involves the welfare of the company's internal executives. According to Pujiati (2013), the higher the bonus compensation given to management, the lower the level of earnings management carried out by company managers. Conversely, the less bonus compensation provided to management, the higher the level of earnings management carried out by company managers. Achmad, et al. (2007) research showing that bonus plans do not motivate earnings management practices. The results differ from Healy (1985), Cheng and Terry (2005) and Cheng, et al. (2011) found that managers with high equity incentives were more likely to manage earnings.

This research gap is a difference from the results of previous studies. Therefore, this study will review earnings management which is affected by bonuses. The bonus in this study was assessed using a dummy variable. This research is a development from Cheng, et al. (2011) who examined the relationship between equity incentives and earnings management. Cheng's research model cannot be applied directly in Indonesia because of differences in economic conditions. Therefore, this study substitutes equity incentives for bonuses. Furthermore, to measure earnings management, researchers use Loan Loss Allowance (LLA) and Loan Loss Provision (LLP) which are still rarely used in Indonesia, while Cheng, et al. (2011) only uses Provision for Loan Loss (LLP).

The banking sector in Indonesia has developed quite well, thus banking has been a source of corporate funding for more than several decades. Banks are regulated industries and have an important role in the economy of a country. Thus, various policies are attached to the bank. According to Lassoued et al. (2017), banks are highly leveraged and have an incentive to take more risks, due to their unique position in financial intermediation and payment systems. The difference in characteristics between the banking industry and other industries, as suggested by Zhou and Weida (2010) that banks operate in a highly regulated environment, and banks that are monitored by the Central Bank and other regulatory agencies, make bank audits more complex than industrial company audits. Regulated industries may have different motivations for managing income (Cheng and Terry, 2005).

LLP (Loan Loss Provision) or CKPN (Allowance for Impairment Losses) is a provision that is determined if the carrying value of a financial asset after an impairment occurs is less than the initial carrying value or measures the level of efficiency and bank fees in establishing an allowance. For productive assets, this is to cover possible risks arising from uncollectible credit facilities or other forms of investment in productive assets (PBI number 14/15 / PBI / 2012). The amount of CKPN will reflect the quality of earning assets, the higher the CKPN, the lower the quality of the productive assets owned by the company, this means that the health of the bank will decline.

According to Cornett et al. (2009) aside from obtaining a smooth profit level, bank managers also perform income smoothing to get bonuses. Banks with high profit and capital levels recorded higher loan losses, especially for banks that applied performance-based bonus managers. This indicates the presumption of earnings management as a result of the manager's desire to report higher earnings, so the opportunity to get a bigger bonus. Research by Ahmad et al. (1999) and Taktak et al. (2010) found that LLP had an effect on earnings before tax in both Islamic and conventional banks.

Loan Loss Allowance (LLA) is a reserve that should be calculated with a certain percentage based on asset quality. The higher the LLA ratio, the higher the probability of bad credit. This means that the quality of the company's productive assets is low. According to Wahlen (1994), allowance for loan losses is an expense recorded to increase the allowance for loan losses and reduce profit before tax for the current period. Jin et al. (2015) stated that banks with higher abnormal LLA took less risk in the pre-crisis period.

\section{METHODS}

This study took the banking population registered in Indonesia in 2015-2017. The sample selection in this study was based on the purposive sampling method (Table 1).

Table 1. Research sample

\begin{tabular}{clc}
\hline No. & Criteria & Total \\
\hline 1. & Banking listed in Indonesia 2015-2017 & 120 \\
2. & Companies that do not publish audited financial statements in full & $(18)$ \\
3. & Companies used as research samples & 102 \\
\hline & Total of observations for 3 years (2015-2017) & 306 \\
\hline
\end{tabular}


This study uses secondary data in the form of audited financial reports and annual reports for 2015-2017. The data comes from the official website of the Indonesia Stock Exchange (IDX), namely www.idx.co.id and from the official websites of each bank. The data analysis method used in this study consisted of one sample t, regression analysis, and classical assumption testing. This study uses SPSS version 19 and Microsoft Excel 2013.

Earnings management is the dependent variable in this study. Earnings management is an effort by management to intervene in preparing financial statements to achieve certain goals. Researchers measure the level of earnings management of Loan Loss Provisions (LLP) using the Kanagaretnam's Model, et al. (2003) while the Loan Loss Allowance (LLA) by using the Hasan and Wall's (2004) model modified by Ujah (2017).

Where,

$$
\mathrm{LLP}_{\mathrm{it}}=\alpha+\beta_{1} \mathrm{NPL}_{\mathrm{it}-1}+\beta_{2} \mathrm{CHNPL}_{\mathrm{it}}+\beta_{3} \mathrm{CHLOAN}_{\mathrm{it}}+\epsilon \ldots
$$

LLP $_{\text {it }} \quad=$ Provision for loan losses deflated by beginning loans

$\alpha \quad=$ Constant

$\beta_{1-3} \quad=$ Regression coefficient

$\mathrm{NPL}_{\mathrm{it}-1} \quad=$ Beginning of period nonperforming loans deflated by beginning loans;

$\mathrm{CHNPL}_{\mathrm{it}} \quad=$ Change in the value of nonperforming loans deflated by beginning loans

CHLOAN $_{i t}=$ Change in value of loans deflated by beginning loans.

$$
\frac{\text { LLA }_{\text {it }}}{\text { Assets }_{\text {it }}}=a_{0} \frac{1}{\text { Assets }_{\text {it }}}+\beta_{1} \frac{\text { NPL }_{\text {it }}}{\text { Assets }_{\text {it }}}+\beta_{2} \frac{\text { NCO }_{\text {it }}}{\text { Assets }_{\text {it }}}+\beta_{3} \frac{\text { LOAN }_{\text {it }}}{\text { Assets }_{\text {it }}}+\beta_{4} \frac{\text { EQUITY }_{\text {it }}}{\text { Assets }_{\text {it }}}+\mathrm{D}+\epsilon_{\text {it }}
$$

Where,

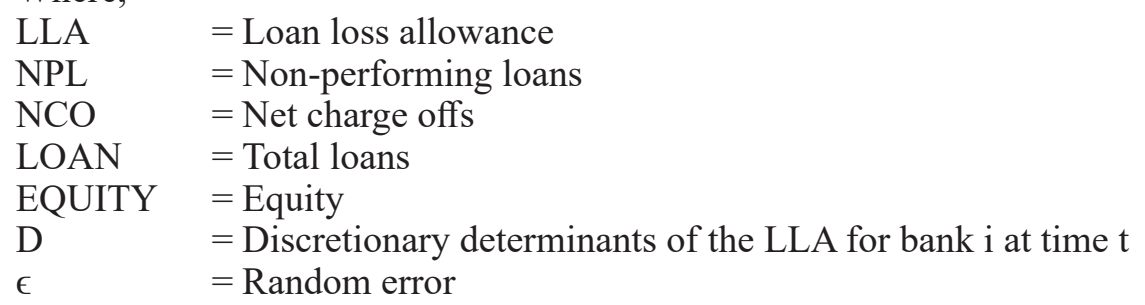

Bonus is an independent variable in this study which will be measured using a dummy variable, where companies that distribute bonuses will be given a score of 1 and companies that do not distribute bonuses will be given a score of 0 (Pujiati and Muhammad, 2013). Control variables are variables that are used to complement the causal relationship to obtain a better empirical model (Hartono, 2007). In this study, the researcher included company size and leverage as control variables. Large companies usually have a role as broader stakeholders, because company size is a value that shows the size of a company. The bigger the company, the greater the opportunity for managers to carry out earnings management. This is because large companies have more complex operational activities and are required to meet higher investor expectations. Mathematically, the size of a company can be measured by the following formula:

$$
\text { Size }=\log (\text { Total Assets })
$$

Leverage is the company's ability to meet its financial obligations. Companies that use debt as the main capital structure are involved in earnings management (Dichev and Skinner, 2000). Leverage in this study is represented by a debt to asset ratio. Mathematically, the debt to asset ratio can be calculated using the following formula:

$$
\text { Debt to Asset Ratio }=\frac{\text { Total Liabilities }}{\text { Total Aset }} \times 100 \%
$$

\section{RESULTS}

In this study, the sample is grouped into samples that are indicated to do earnings management and samples that are not indicated to do earnings management. The procedure for grouping samples using abnormal LLP and abnormal LLA is in accordance with the research conducted by Amidu and Ransome (2015). Companies are indicated to carry out earnings management if the abnormal LLP and abnormal LLA values are less than the predicted LLP and predicted LLP values. Tables 2 and 3 are tables that present banks that are indicated to carry out earnings management and banks that are not indicated to carry out earnings management in the study sample. 
Table 2. Samples Indicated of Conducting Earnings Management using LLP

\begin{tabular}{ccc}
\hline Year & Indicated Earnings Management & No indication of earnings management \\
\hline 2015 & 71 & 31 \\
2016 & 72 & 30 \\
2017 & 67 & 35 \\
\hline Total & 210 & 96 \\
\hline
\end{tabular}

Table 2 explains that in 2015, out of 102 banks, 71 banks were indicated to have carried out earnings management by reducing the LLP value. In 2016, out of a total of 102 banks registered in Indonesia, there were 72 indicated that they were doing earnings management by reducing the LLP value. Of the 102 registered banks in Indonesia in 2017, 67 banks were indicated to have carried out earnings management by reducing the LLP value.

Table 3. Samples Indicated of Conducting Earnings Management using LLA

\begin{tabular}{ccc}
\hline Year & Indicated Earnings Management & No indication of earnings management \\
\hline 2015 & 89 & 13 \\
2016 & 88 & 14 \\
2017 & 90 & 12 \\
\hline Total & 267 & 39 \\
\hline
\end{tabular}

Table 3 explains that in 2015, out of 102 banks there were 89 by reducing the LLA value. In 2016, out of a total of 102 banks registered in Indonesia, there were 88 by reducing the LLA value. In 2017, there were 90 banks registered in Indonesia out of a total of 102 banks that carried out earnings management by reducing the LLA value.

Furthermore, to find out whether or not there are earnings management practices in banks, a different test is performed using the one sample $t$ test. The results of different tests regarding whether banks carry out earnings management by reducing LLP and LLA values are presented in the Table 4.

Table 4. Results of the One Sample T Test Analysis

\begin{tabular}{cccccc}
\hline & $\mathrm{N}$ & $\mathrm{T}$ & $\mathrm{Df}$ & Sig. & Mean \\
\hline LLP & 306 & -.271 & 305 & .787 & -.000456 \\
LLA & 306 & -.14 .929 & 305 & .000 & -.021373 \\
\hline
\end{tabular}

From the results of different tests using the one sample $t$ test, it is found that the LLP proxy is Sig 0.787> $\alpha 0.05$, so the conclusion is that banks do not carry out earnings management by reducing the LLP value. The practice of LLA proxy earnings management has a value of Sig $0,000<\alpha 0.05$, so the conclusion is that banks carry out earnings management by reducing the LLA value.

This study uses a normal probability plot for normality testing. A regression equation is said to be normal if the points or data are near or follow a diagonal line, it can be said that the residual value is normally distributed. The results of the normality test in this study show that the plot points always follow and approach the diagonal line. Thus, the assumption of normality in the linear regression analysis in this study can be fulfilled.

To detect the presence or absence of multicollinearity, it can be seen from the tolerance value and Variance Inflation Factor (VIF). The multicollinearity test results can be seen in Table 5.

Table 5. Multicollinearity Test Results

\begin{tabular}{lcccc}
\hline & \multicolumn{2}{c}{ Loan Loss Provisions (LLP) } & \multicolumn{2}{c}{ Loan Loss Allowance (LLA) } \\
\cline { 2 - 5 } & Tolerance & VIF & Tolerance & VIF \\
\hline Bonus (Dm_KB) & 0.994 & 1.006 & 0.994 & 1.006 \\
SIZE (SIZE) & 0.996 & 1.004 & 0.996 & 1.004 \\
Leverage (LEV) & 0.991 & 1.009 & 0.991 & 1.009 \\
\hline
\end{tabular}

Based on Table 5, the tolerance value for the bonus variable is $0.994>0.01$, the tolerance value for the firm size variable is $0.996>0.01$, and the tolerance value for the leverage variable is $0.991>0.01$. while the VIF value for the bonus variable was $1.006<10.00$, the VIF for the variable company size was $1.004<10.00$, and the VIF for the leverage variable was $1.009<10.00$. So it can be concluded that multicolineartias symptoms do not occur. 
Table 6. Results of Linear Regression Analysis

\begin{tabular}{|c|c|c|c|c|c|c|}
\hline & \multicolumn{3}{|c|}{ Loan Loss Provisions (LLP) } & \multicolumn{3}{|c|}{ Loan Loss Allowance (LLA) } \\
\hline & Koefisien Regresi & $\mathrm{T}$ & Sig. & Koefisien Regresi & $\mathrm{T}$ & Sig. \\
\hline Dummi Bonus & -0.130 & -2.371 & 0.018 & 0.003 & 0.048 & 0.962 \\
\hline Size (control v.) & -0.030 & -0.554 & 0.580 & 0.003 & 0.056 & 0.955 \\
\hline Leverage (control v.) & -0.303 & -5.528 & 0.000 & 0.119 & 2.066 & 0.040 \\
\hline $\mathrm{F}$ value & & 11.482 & & & 1.428 & \\
\hline $\mathrm{R}$ square & & 0.102 & & & 0.014 & \\
\hline
\end{tabular}

From Table 6, it is known that the variable dummi bonus has a negative effect on earnings management practices, which is proxied by the loss loans provision. The hypothesis which states that the bonus has a positive effect on earnings management of the loan loss provision is not proven. The variable dummi bonus has no effect on earnings management practices as proxied by the loan loss allowance. The hypothesis which states that bonus has a positive effect on earnings management loan loss allowance is not proven.

The control variable firm size on LLP proxy has a t-count of -0.554 with a significance level of 0.580 . LLA proxy company size has a t-count of -0.056 with a significance level of 0.955 . The level of significance is above 0.05. This means that firm size has no effect on the proxy earnings management of LLP or LLA. The leverage control variable on the LLP proxy has a t-count of -5.528 and a significance value of 0.000 . Leverage in the LLA proxy has a t-count of 2.066 with a significance level of 0.040 . The significance value $>0.05$, it can be concluded that leverage has an effect on the proxy earnings management of LLP and LLA.

\section{DISCUSSIONS}

The result of this research states that managers perform earnings management by reducing the value of the loan loss allowance and not by means of the loan loss provision. This means that the hypothesis which says that managers perform earnings management by reducing the value of the loan loss provision is rejected, while the hypothesis which says that managers perform earnings management by reducing the value of the loan loss allowance is accepted. The results of this study reject the research conducted by Amidu and Ransome (2015) which states that companies carry out earnings management using a loan loss provision.

Loan loss allowance or commonly known as allowance for credit losses is closely related to the balance sheet. The relationship between LLA and the balance sheet is because LLA is one of the balance sheet components that reduces the value of loans in banks. As a result, the smaller the LLA value, the total banking assets will increase, and vice versa, the increase in LLA value will decrease the company's total assets. The increase in loan out-of-stock must be covered by earning asset reserves by debiting the cost of earning assets reserves and crediting the reserve account for earning assets losses. If the level of credit risk at a bank is high, the cost of reserves for earning assets and other assets will also be large.

The results of a series of tests conducted by researchers indicate that there is a negative effect of bonuses on earnings management. This shows that the smaller the bonus given, the more the company performs earnings management. This evidence corroborates previous findings regarding the motivation for opportunistic behavior related to compensation, this is in line with the research of Neifar et al. (2016) and Achmad, et al. (2007) that manager compensation has a negative effect on the level of earnings management. The results of this study are not in line with research conducted by Healy (1985); Cheng and Terry (2005); Meek, et al. (2007); Noronha, et al. (2008); and Cheng, et al. (2011) who stated that bonuses have a positive effect on earnings management.

Banking managers will get a bonus if the profit value is equal to or greater than the value of last year's profit. This will benefit managers, so that managers are motivated to carry out earnings management in order to maintain the bonus received. This study explains that the company uses the Loan Loss Provision proxy in performing earnings management. According to Ozili (2017) the reason for using LLP is that LLP is the most significant discretionary accrual that bank managers have and LLP has a direct impact on bank interest margins and overall income. Giving bonuses can have the effect of encouraging managers to use accounting policies in reporting higher earnings, whereas this study finds evidence that bonuses have a negative effect on earnings management practices. The results of this study are not in accordance with the positive accounting theory, the first hypothesis is the bonus program hypothesis, because in this study the more bonuses that are given the less earnings management practices are given.

Bonuses do not have an effect on the discretionary loan loss allowance because LLA is a component of the balance sheet, while the bonus is based on company profits. The results of this study are consistent with the 
research of Healy and Wahlen (1999); Leventis and Dimitropoulos (2012); Barghathi (2017) all concluded that banks use LLP as a tool for aggressive earnings management (manipulation).

The rejection of the hypothesis that bonuses have a positive effect on management proxied by LLP is because banks do not carry out earnings management using LLP proxies (according to hypothesis H1a). The emergence of a negative effect on the relationship between bonuses on LLP proxy earnings management is because the bonuses given are considered high enough, so that managers are at the stage of not doing earnings management. The rejection of the hypothesis that bonuses have a positive effect on management proxied by LLA. Empirical evidence that banks perform LLA proxy earnings management because bonuses do not motivate managers in managing LLA proxy earnings. LLA is a balance sheet account, while bonuses are mostly based on profits.

In accordance with the theoretical basis used, namely the positive accounting theory, the first hypothesis presented by Watts and Zimmerman (1986), states that earnings management motivation is a bonus program. The results of this study do not support the positive accounting theory that underlies the motivation for earnings management practices. The findings of this study indicate that bonuses have a negative effect on earnings management practices. This provides an understanding that the bonus received by the manager is able to change management behavior as a company financial report maker, namely the higher the bonus the lower the earnings management practice.

\section{CONCLUSIONS}

This study aims to determine earnings management practices in banking. This study also aims to determine the motivation for earnings management practices. The theoretical basis used in this research is the positive accounting theory, the first hypothesis. This theory serves to explain the relationship between bonuses and earnings management. The sample used in this study were 102 registered banks in Indonesia. This study uses abnormal LLP and abnormal LLA measurement tools to classify a sample of banks that are indicated or not indicated to be performing earnings management. This study provides empirical evidence that banking in Indonesia tends to carry out earnings management by reducing the LLA value. This study provides empirical evidence that bonuses are able to influence earnings management practices in Indonesian banking in a negative direction. It is evident from the results of LLP proxy earnings management testing that managers will reduce earnings management practices if the bonuses given are higher.

\section{REFERENCES}

Achmad, K., Subekti, I. and Atmini, S., 2007. Investigasi Motivasi dan Strategi Manajemen Laba pada Perusahaan Publik di Indonesia. Jurnal Tema, 8(1).

Ahadiat, N. and Hefzi, H., 2013. An Investigation of Earnings Management Practices: Examining Generally Accepted Accounting Principles. International Journal of Business and Social Science, 3(14).

Ahmed, A.S., Takeda, C. Thomas, S. 1999. Bank Loan Loss Provisions: a Re-examination of Capital Management, Earnings Management and Signalling Effects. Journal of Accounting and Economics, Vol. 28 No, 1-25

Amidu, M. and Kuipo, R., 2015. Earnings Management, Funding and Diversification Strategies of Banks in Africa. Accounting Research Journal.

Astari, A.A.M.R. and Suryanawa, I.K., 2017. Faktor-Faktor yang Mempengaruhi Manajemen Laba. E-Jurnal Akuntansi, 20(1), pp.290-319.

Barghathi, Y. 2017. Stakeholders' Perceptions on Earnings Management And, Motivations and Techniques in Libyan Commercial Banks. Accounting Management Information System, Vol 16, No, 344-368.

Belkaoui, A. R. 2012. Teori Akuntansi. Jakarta: Salemba Empat.

Cheng, Q. and Warfield, T.D., 2005. Equity Incentives and Earnings Management. The Accounting Review, 80(2), pp.441-476.

Cheng, Q., Warfield, T. and Ye, M., 2011. Equity Incentives and Earnings Management: Evidence from The Banking Industry. Journal of Accounting, Auditing \& Finance, 26(2), pp.317-349.

Chhabra, M. S. 2016. Earning Management: A Study. Splint International. Journal of Professionals, 3,(11).

Dechow, P.M., Sloan, R.G. and Sweeney, A.P., 1995. Detecting Earnings Management. Accounting Review, pp.193-225.

Elfira, A., 2014. Pengaruh Kompensasi Bonus Dan Leverage Terhadap Manajemen Laba (Studi Empiris Pada Perusahaan Manufaktur yang Terdaftar di Bursa Efek Indonesia Tahun 2009-2012). Jurnal Akuntansi, 2(2).

Farook, S., Hassan, M.K. and Clinch, G., 2014. Islamic Bank Incentives and Discretionary Loan Loss Provisions. Pacific-Basin Finance Journal, 28, pp.152-174. 
Fudenberg, D. and Tirole, J., 1995. A Theory of Income and Dividend Smoothing Based on Incumbency Rents. Journal of Political economy, 103(1), pp.75-93.

Gayatrie, C. R. 2014. Skema Bonus dalam Keputusan Akuntansi Manajer. JABPI, 22.

Ghozali, I. 2011. Aplikasi Analisis Multivariate dengan Program SPSS. Semarang: Universitas Diponegoro.

Habbash, M. and Alghamdi, S., 2015. The Perception of Earnings Management Motivations in Saudi Public Firms. Journal of Accounting in Emerging Economies.

Hamisyah, N., Setyadi, D. and Yudaruddin, R., 2018. Dampak Krisis dan Kinerja Keuangan terhadap Loan Loss Provision. KINERJA, 15(1), pp.14-20.

Healy, P.M. and Wahlen, J.M., 1999. A Review of The Earnings Management Literature and Its Implications for Standard Setting. Accounting horizons, 13(4), pp.365-383.

Hua, Z. and Wei-da, K., 2010. The Information Sharing in Banking Regulation and Accounting Regulation a Case Study on the Regulatory Rules of Loan Loss Allowances. In 2010 International Conference on Management Science \& Engineering 17th Annual Conference Proceedings (pp. 1137-1145). IEEE.

Indriantoro, N. and Bambang, S., 2014. Metodologi Penelitian Bisnis, Edisi Pertama, Cetakan Keenam. Badan Penerbit Fakultas Ekonomi Universitas Gadjah Mada. Yogyakarta.

Jin, J., Kanagaretnam, K. and Lobo, G.J., 2018. Discretion in Bank Loan Loss Allowance, Risk Taking and Earnings Management. Accounting \& Finance, 58(1), pp.171-193.

Jones, J.J., 1991. Earnings Management During Import Relief Investigations. Journal of Accounting Research, 29(2), pp.193-228.

Kanagaretnam, K., Lim, C.Y. and Lobo, G.J., 2010. Auditor Reputation and Earnings Management: International Evidence from The Banking Industry. Journal of Banking \& Finance, 34(10), pp.2318-2327.

Koch, T.W., Waggoner, D.F. and Wall, L.D., 2018. Incentive Compensation, Accounting Discretion and Bank Capital. Journal of Economics and Business, 95, pp.119-140.

Lassoued, N., Attia, M.B.R. and Sassi, H., 2017. Earnings Management and Ownership Structure in Emerging Market: Evidence from Banking Industry. Managerial Finance.

Leventis, S., P. D. 2012. The Role of Corporate Journal, Governance in Earnings Management: Experience from Us Banks. Journal of Applied Accounting Research, Vol. 13 No, 161-177.

Li, Y., Nie, W., Xiang, E. and Djajadikerta, H.G., 2018. Can banks identify firms' real earnings management? Evidence from China. Finance Research Letters, 25, pp.23-29.

Neifar, S., Halioui, K. and Abdelaziz, F.B., 2016. The Motivations of Earnings Management and Financial Aggressiveness in American Firms Listed on The NASDAQ 100. Journal of Applied Accounting Research.

Ningsih, S. 2015. Earning Management Melalui Aktivitas Riil dan Akrual. Jurnal Akuntansi Dan Pajak, Vol. $16,55-66$.

Ozili, P. K. 2017. Bank Earnings Management and Income Smoothing Using Of Commission and Fee Income A European Context. International Journal Managerial Finance, Vol. 13 No, 419-439.

PBI. 2012. Peraturan Bank Indonesia Nomor 14/15/PBI/2012. Kualitas Aset Bank Umum.

Pratiwi, M.W., 2012. Skema Bonus dalam Keputusan Akuntansi. Media Riset Akuntansi, 1(1).

Pujiati, E.J. and Arfan, M., 2013. Struktur Kepemilikan dan Kompensasi Bonus Serta Pengaruhnya Terhadap Manajemen Laba pada Perusahaan Manufaktur yang Terdaftar di Bursa Efek Indonesia Tahun 2006-2010. Jurnal Telaah dan Riset Akuntansi, 6(2), pp.122-139.

Purwanti, L., 2010. Kecakapan Managerial, Skema Bonus, Managemen Laba, dan Kinerja Perusahaan. Jurnal Aplikasi Manajemen, 8(2), pp.430-436.

Scott, W. R. 2015. Financial Accounting Theory, 6th edition. Canada: Prentice Hall Inc., Canada.

Subekti, I., 2010. Engaging in Earnings Management to Avoid Negative Earnings. Jurnal Akuntansi Multiparadigma, $1(1)$, pp.24-41.

Subekti, I. 2012. Accrual and Real Earnings Management: One of the Perspectives of Prospect Theory. Journal of Economics, Business, And Accountancy Ventura, vol 15, $443-456$.

Taktak, N.B., Zouari, S.B.S. and Boudriga, A., 2010. Do Islamic Banks Use Loan Loss Provisions to Smooth Their Results?. Journal of Islamic Accounting and Business Research.

Ujah, N.U., Brusa, J. and Okafor, C.E., 2017. The Influence of Earnings Management and Bank Structure on Bank Performance: International Evidence. Managerial Finance.

Undang-Undang no 21 tahun 2008 tentang Perbankan Syariah

Undang-Undang No.10 tahun 1998 tentang Perubahan Atas UU No. 7 Tahun 1992 tentang Perbankan

Utomo, S., 2011. Skema Bonus Dewan Direksi dan Aktivitas Manajemen Laba (Penelitian pada Perusahaan Manufaktur di BEI). Jurnal Dinamika Ekonomi \& Bisnis, 8(1).

Watts, R.L. and Zimmerman, J.L., 1986. Positive Accounting Theory. New York: Prentice-Hall. 
Wijaya, V.A. and Christiawan, Y.J., 2014. Pengaruh Kompensasi Bonus, Leverage, dan Pajak terhadap Earning Management pada Perusahaan yang Terdaftar di Bursa Efek Indonesia Tahun 2009-2013. Tax \& Accounting Review, 4(1), p.316.

Wijayanti, R. and Diyanti, V., 2017. Pengaruh Volatilitas Laba, Perataan Laba dan Corporate Governance terhadap Kualitas Laba Bank Syariah dan Konvensional. Muhammadiyah University Yogyakarta.

Zang, A. Y. 2012. Evidence on the Trade-Off between Real Activities Manipulation and Accrual-Based Earnings Management. The Accounting Review, Vol. 87, N, 675-703.

Zhou, H. and Kuang, W., 2010, November. Banking Management, Loans Loss Allowance and Accounting Standard. In 2010 3rd International Conference on Information Management, Innovation Management and Industrial Engineering (Vol. 4, pp. 60-64). IEEE. 